JOURNAL OF CORPORATE RESPONSIBILITY

AND LEADERSHIP

Contemporary Issues in Corporate Social Responsibility

\title{
Dialogue with the environment: A new challenge for the practice of responsible leadership
}

DOI: http://dx.doi.org/10.12775/JCRL.2014.002

\begin{abstract}
JACEK DYMOWSKI ${ }^{\mathrm{a}}$
aAbadon Consulting, Warszawa, Poland; external expert of the Department of Management Theory, Warsaw School of Economics, Warsaw, Poland e-mail: jacek.dymowski@abadon.pl
\end{abstract}

\begin{abstract}
The paper copes with the issue of the company dialogue with its stakeholders, which is considered to be one of the contemporary challenges for management and business leaders. It reviews not only theoretical approach, but is the discussion of today's business practice. It focuses on the constructive critique of "stakeholders panels", which show to be ineffective. The aim of the paper is to propose an alternative governance solution, which may make sustainability governance more effective.
\end{abstract}

Keywords: sustainability governance, responsible management, stakeholder panels, stakeholder engagement.

\section{Introduction}

It is impossible to write and talk about social responsibility in management without mentioning the involvement of stakeholders, including the dialogue with them. Taking into the account the expectations and interests of the groups of stakeholders (i.e. groups which have an impact on an organization or an organization affects them) is the foundation of responsible management. The concept of engaging stakeholders is reflected directly in all the key standards, norms and guidelines 
concerning corporate social responsibility (e.g. ISO 26000 standard and GRI Reporting Guidelines). However, the gap is observed between the theory of management and the official standards and the daily business practice. Business leaders are somewhat reluctant to adopt the solutions recommended on the basis of the theory and standards. The problems of involving a broad spectrum of stakeholders and the organizational approaches to include their opinions in decision making processes are the fields of interest of this paper. The purpose of the publication is to study the potential limitations of the approaches observed in Polish companies. Moreover, the paper discusses the best organizational solutions concerning stakeholder engagement.

\section{Engaging stakeholders - the management theory perspective $\mathbf{e}^{1}$}

At the beginning, the theory of stakeholders and its genesis are worth mentioning. This theory is most often contrasted with the theory of shareholders, proclaiming the primacy of shareholders' profits. The theory of stakeholders derives from strategic management and it was introduced by Freeman (Freeman and 1984). In contrast to the theory of shareholders, it assumes that the purpose of the enterprise is to build value not only for the owners, but for the benefit of a wider group. The theory defines the concept of stakeholders ${ }^{2}$, i.e. all of these institutions, individuals or groups of people, on which an organization has an impact or which have an impact on an organization. In the narrower sense, stakeholders can be alternatively defined as these groups, which are critical to further operations of an organization (Freeman and Reed, 1983). Certainly, in business practice, the company impact may create different results: a company can create value for its stakeholders, but it can also destroy this value. In the perspective of the stakeholder theory, corporations are obliged to take into account their influence and the interests of social groups other than just shareholders, going even beyond legal requirements (Jones, 1980, pp. 59-67). The key role of dialogue with stakeholders, in order to obtain legitimacy for action, is strongly stressed in this theory (Freeman and Liedtka, 1991, pp. 92-99).

1 This passage is an excerpt from Dymowski (2012, pp. 22-25).

2 The concept of "stakeholders" first appeared in 1963 in the memorandum of Stanford Research Institute. 
While the shareholder theory is based on the foundation of the philosophy of Lock, which puts an individual and their personal objectives in the center of its attention, the stakeholder theory grows out from the philosophy of Kant, anticipating a respect for other people. The natural consequence of respect for the environment is taking it into account when making decisions, or the openness to dialogue concerning social expectations. In order to emphasize the central role of stakeholders, Freeman and Velmuri (2006) proposed a new explanation of the CSR acronym in English (Corporate Social Responsibility), in which the word "social", was replaced by the word "stakeholder". It means that instead of Corporate Social Responsibility, a company should be responsible to stakeholders (Corporate Stakeholders Responsibility).

Evan and Freeman (1988) developed the theory of stakeholders based on two ethical principles:

- the Principle of Corporate Right, which proclaims that a company and managers must not violate the irrefutable rights of third parties to shape their future;

- the Principle of Corporate Effects which, in turn, says that a company and managers are responsible to others for the consequences of their actions.

These rules were supplemented by two additional Stakeholder Management Principles:

- a company should be managed for the benefit of stakeholders: customers, suppliers, owners, employees and local communities. The rights of these groups should be ensured, and what is more, these groups should, in some sense, participate in making decisions that may affect them;

- managers are bound by trust relationship with stakeholders and a company considered as an abstract entity. They must play the role of agents representing the interests of stakeholders, and act in the interests of a company, ensuring its existence and survival, and protecting the long-term interests of each group of stakeholders.

In business practice, theoretical foundations proposed by Freeman are reflected in the code developed by the Clarkson Center for Business Ethics (1999). This theory has a very strong relationship with the theory of corporate social performance. It puts much emphasis on the need of dialogue with the stakeholders and the social legitimacy of the business activity. 
In the theory of Enlightened Shareholders Value, Jensen (1986) manages to reconcile the theories of stakeholders and shareholders which originally have seemed to be contradictory. What is more, Mele (2009, p. 66) claims that one of the key advantages of the Stakeholder Theory is to give an ethical dimension to the Shareholders Theory. The assumption that the creation of long-term values for stakeholders means building value for owners of capital strengthens the moral sense of the Shareholders Theory.

The multitude of purposes should be mentioned as one of the theory weaknesses due to the fact that managers lack a clear guideline. Therefore, the multitude of objectives may result in the lack of effective implementation of any of them. The theory of strategic management suggests that there should be only one strategic goal at a given period of time. When there are two or three goals, it is still possible to order them in the hierarchy. However,

the problem arises when there are more strategic objectives, which is common in business practice. It is difficult to establish their clear hierarchy. The problem of their mutual consistency and transitivity emerges (in the extreme case the objective 1 is more important than the objective 2, the objective 2 is more important than the objective 3 , but in a given period of time the objective 3 may be more important than the objective 1 etc.). Such a situation results in all kinds of rivalry for power, influence and resources (Obłój, 2010, p. 84).

This issue triggers other practical problems. The multitude of business goals and decision-makers (stakeholders) makes effective management very difficult, or even impossible. Except for the already mentioned conflicts for power or the allocation of resources, the agency conflict may be aggravated. In theory, a manager who should act as a trustee on behalf of all stakeholders and at the same time should take care of the interest of each individual stakeholder. In practice, a manager may choose these expectations and solutions, which best meet their own goals contributing to the development of a company (cf. Jensen, 1986; Marcoux, 2000; Sternberg, 2000). Moreover, the problems of quantification, measurability and comparability of different activities are observed. How parallel objectives can be achieved at the same time? How to measure them and compare them when they are incomparable? How to assess managers for the results? The aforementioned dilemmas are emphasized by Sternberg (2000, p. 51) who claims that the stakeholder theory "effectively destroys business accountability...because 
a business that is accountable to all, is actually accountable to none”. This, in consequence, raises the question of monetization, i.e. using money as a common measure for the purposes other than economic, and the related issues of moral and ethical nature.

\section{Engaging stakeholders - the business practice perspective}

As already mentioned, in business practice, the concept of stakeholders' engagement in the decision-making process practice is highlighted by the ISO 26000 standard, which makes it one of the principles of social responsibility. The standard (PN-ISO 26000, pp. 24-25) reads:

The principle is: an organization should respect, consider and respond to the interests of its stakeholders. Although an organization's objectives may be limited to the interests of its respective owners, members, customers or constituents, other individuals or groups may also have rights, claims or specific interests that should be taken into account. Collectively, these individuals or groups comprise the organization's stakeholders. An organization should: identify its stakeholders; be conscious of and respect the interests of its stakeholders and respond to their expressed concerns; recognize the interests and legal rights of stakeholders; recognize that some stakeholders can significantly affect the activities of the organization; assess and take into account the relative ability of stakeholders to contact, engage with and influence the organization; take into account the relation of its stakeholders' interests to the broader expectations of society and to sustainable development, as well as the nature of the stakeholders' relationship with the organization; and consider the views of stakeholders that may be affected by a decision even if they have no formal role in the governance.

The standard stresses the critical role of two fundamental practices of social responsibility. They are the prerequisites to say that operations are taken in accordance with the principles of responsibility. Those principles are (PN-ISO 26000, p. 29):

- recognizing social responsibility;

- stakeholder identification and engagement.

Similarly, the principle of stakeholders' engagement is included in all versions of GRI reporting guidelines. Stakeholders Inclusiveness, Materiality, Completeness and Sustainability Context are the principles defining the scope of a social report (GRI, 2013, pp. 13, 16-17).

Moreover, the AA1000 SES standard is worth mentioning. It is a very practical tool, the manual how to conduct the step-by-step dialogue with stakeholders. The standard indicates the steps that must be followed in 
the process of dialogue, reminding even obvious tasks to do, such as sending invitations. However, some crucial elements related to defining the stakeholders engagement process should be emphasized. First of all, it is necessary to define the scope (what?), purpose (why?), and key stakeholders (who?) of dialogue. Secondly, there is an obligatory feedback, which should be given at the end of the process to all interested parties on all expectations, including those rejected by an organization.

\section{Engaging stakeholders - the perspective of Polish companies}

Having in mind the point of view of an ordinary entrepreneur, the question about the purpose of organizing dialogue processes should be asked. Contrary to appearances, the question is not trivial, and the answer is not necessarily obvious. It seems to be relatively simple in the case of dialogue which is focused on a very specific case, i.e. a greenfield investment, which raises concern among the local community. Such a meeting has a concrete purpose and it can result in concrete outcomes. The only requirement is to have all the parties willing to clarify concerns and to develop a consensus, not just fill the legal requirements concerning 'social dialogue'. Therefore, this type of dialogue processes should not be seen as controversial from the managerial point of view.

However, some doubts may arise in case of dialogue, in which the company strategy is discussed, with a particular focus on "stakeholder panels" which are very fashionable nowadays. These are the workshops for broadly defined representatives of stakeholder groups, which are focused for example on discussion on foundations of the company's strategy. Are companies really so interested to make all their confidential plans public? Would it be rational?

The simple analysis of companies which participated in the competition "Social Reports 2013" (Table 1), indicates that only a few of them decided to engage stakeholders in the form of "stakeholder panels". It should be emphasized that reporting companies are a kind vanguard of social responsibility. It can be assumed, with a large degree of probability, that in this group of reporting companies, majority or even all companies organizing 'stakeholder panels' are included.

The study shows that only six companies among the participants of “Social Reports 2013” engage their stakeholders in "stakeholder panels". 
Table 1. "Stakeholder panels” in companies participating in "Social Reports 2013”

\begin{tabular}{|c|c|c|c|}
\hline Organization & AA1000 SES & $\begin{array}{l}\text { Stakeholder } \\
\text { panel }\end{array}$ & $\begin{array}{l}\text { Page in social } \\
\text { report }\end{array}$ \\
\hline \multicolumn{4}{|l|}{$\begin{array}{l}\text { Związek Pracodawców Polski } \\
\text { Przemysł Spirytusowy }\end{array}$} \\
\hline RWE Polska & yes & yes & p. $67-68$ \\
\hline \multicolumn{4}{|l|}{ Coca-Cola HBC Polska } \\
\hline \multicolumn{4}{|l|}{ Fundacja Lotto Milion Marzeń } \\
\hline \multicolumn{4}{|l|}{ Agencja Zatrudnienia ATERIMA } \\
\hline Totalizator Sportowy & & yes & p. 58 \\
\hline \multicolumn{4}{|l|}{ GlaxoSmithKline (GSK) } \\
\hline \multicolumn{4}{|l|}{ ING Bank Śląski } \\
\hline \multicolumn{4}{|l|}{ Katowicki Holding Węglowy } \\
\hline Grupa Kapitałowa Żywiec & yes & yes & p. 47 \\
\hline Kompania Piwowarska & yes & yes & p. 59 \\
\hline \multicolumn{4}{|l|}{ Comarch } \\
\hline Tauron & yes & yes & p. 28 \\
\hline \multicolumn{4}{|l|}{ KGHM } \\
\hline \multicolumn{4}{|l|}{ SKOK Ubezpieczenia } \\
\hline \multicolumn{4}{|l|}{ Pelion } \\
\hline \multicolumn{4}{|l|}{ PKN Orlen } \\
\hline \multicolumn{4}{|l|}{ Grupa Lotos } \\
\hline \multicolumn{4}{|l|}{ Budimex } \\
\hline \multicolumn{4}{|l|}{ Tesco } \\
\hline \multicolumn{4}{|l|}{ Unilever } \\
\hline Orange Polska & yes & yes & p. 21 \\
\hline Bank BPH & & & \\
\hline
\end{tabular}

Source: Own study based on social reports.

The findings determine a question about advisability and effectiveness of such a solution. Except for the fact that no company, due to its interests, will disclose critical elements of its strategy, including the CSR strategy, there are some doubts regarding the sense of such an approach.

There is an impression that "stakeholder panels" are meetings "for everyone and about everything”. In practice, this could mean a meeting 
“for no one and about nothing”. Meetings, which are related to such broad issues and invite very broad audience, probably give no chance for substantial and meaningful discussion on real expectations and fears. Such panels become "PR tools" to show the public acceptance of planned activities and to "proof" the social license to operate. Criticizing this type of mechanism, it is worth paying attention to the audience. Due to the way of organizing this type of meetings, in the language of the market research, the audience is not a representative research sample. Such an approach is simply a mistake from the point of view of market research and it has an impact on the reliability of results. When organizing "stakeholder panels" random people may be found in the room. In practice, the structure of a panel is, as mentioned, out of control. Invitations are sent to a large audience. No one can expect how many representatives of each stakeholder group will attend the meeting, e.g. how many representatives of customers will be there, how many suppliers will participate, who will dominate the discussion, etc. The proportions can spread quite randomly. One group may be overrepresented, and another one may be virtually absent. If there is a person who dominates the discussion, the voice and the problems of one of the groups will become suddenly a priority, etc. In consequence, the discussed problems may not be priorities for the population of all stakeholders. The issue of the statistical significance of such studies is over discussion. Looking at the problem through the prism of the AA1000 standard SES as well as market research methodology, the weakness of modern gatherings, known as "stakeholder panels", becomes evident.

Nevertheless, there are some advantages of "stakeholder panels". Organizing them is relatively cheap, at least compared to the alternative, traditional market research. There are some other factors which make them quite popular, i.e. they are promoted by some consulting companies and they are quite modern. There is a supposition that brand image plays an important role, too. It is probably more important than understanding stakeholders' expectations. Ironically, one could say: If the goal is solely to be able to say that such a meeting took place, actually "stakeholder panels" are good. From the point of view of the brand image, panels support the communication to convey the message about the company concern on stakeholders engagement. The G4-26 indicator of the GRI guidelines may be reported. A company may boast of social acceptance for its plans and the social license to operate. Nevertheless, the real business value of "stakeholder panels" is very limited. 
If a company really wants to examine the expectations and concerns of stakeholders' groups, a different approach is recommended. The approach which is comprehensive, quite complex, tedious but unfortunately quite expensive. The approach, which for many years has been successfully applied by market researchers, regardless of the subject of their studies. In simple terms: the first step is to conduct qualitative studies (e.g. FGI) that allow a company to capture and describe issues which really matter. In the next step, quantitative research tools are applied to provide the statistical analysis. This allows a company to verify the hypothesis about the real meaning of the data for the test. For years, such an approach has been successfully applied in the surveys of customer or employee opinions. The same approach may be employed to study the other groups of stakeholders. The approach is universal. Interestingly, virtually every large enterprise regularly examines its customers' feedback and satisfaction. Customer satisfaction factor is even treated as a determinant of success and a business objective for managers. No one is surprised if a company analyses employee satisfaction. However, it is difficult to find a company which applies similar universal tools more broadly, i.e. to analyze feedback and satisfaction of all relevant groups of stakeholders. It is also worth mentioning that the researchers have some other interesting tools, such as participatory planning, explicitly created to work with the representatives of local communities. The tools have been known for years, and they allow companies to acquire real knowledge about their stakeholders' key expectations and fears.

There was an idea to build such a comprehensive tool, i.e. the comprehensive series of interviews, focus groups, quantitative research, supplemented with a participatory workshop, which would be an analogy of the " $360^{\circ}$ " assessment. The company would be assessed by different groups of stakeholders. It was offered to several large enterprises described above, but the proposal failed ${ }^{3}$. It may confirm the thesis that "stakeholder panels" are more brand image driven, rather than motivated by real needs to identify stakeholder expectations.

However, the lack of interest in the comprehensive approach mentioned above, may be explained in a completely different way. As

${ }^{3}$ Such a proposal was offered to more than a dozen of large companies, leaders in corporate social responsibility in Poland in 2011. The proposal was developed by the Author of the paper in cooperation with a leading research company. 
regards "stakeholder panels", they are organized by the staff responsible for managing the company social responsibility. The panels are usually established when the CSR strategy is being developed or social reports are being prepared. However, the lack of comprehensive dialogue processes conducted by CSR staff should not be interpreted as a lack of dialogue and the involvement of stakeholders. None of the companies operate in a vacuum. There are other entities in the organizational structure that recognize needs, expectations and concerns of the various groups of stakeholders e.g. they survey customer and employee satisfaction, carry out meetings with suppliers, conduct joint projects with non-governmental organizations (NGOs), or meet face-to-face with the representatives of the administration. The variety of forms of decentralized dialogue may be found in social reports. The examples of best practices in this area are discussed by Dymowski (2014, pp. 30-49). All these activities are the forms of the dialogue with stakeholders. All of them engage stakeholders to a lesser or greater extent. The only difference is that the process itself is decentralized, i.e. there is no one organizational cell, which officially coordinates the whole knowledge of the expectations of individual groups. On the one hand, such a decentralized approach is certainly more flexible. On the other hand, it involves the risk of inefficient management of knowledge about the business environment (e.g. lack of skill to manage the contradictory expectations of different groups on behalf of the company's interest). It should be noted that the lack of formal coordination, within the meaning of the establishing a dedicated business unit, does not mean that such a function is not carried out within the framework of the activities of some existing organizational units. For instance, this function can be performed by the Board of Directors, which draws information from the whole organization. One can also imagine a solution in which the knowledge obtained within each functional business unit is aggregated and analyzed by the CSR Committee. The Committee, which collects knowledge from an organization, but it does not obtain it independently. Once again, it is worth pointing out that not always top-down attempts to centralize the management of dialogue processes are reasonable. Individual operational managers have a good understanding of the expectations and concerns of company stakeholders. They have such knowledge because they cooperate with stakeholders on a daily basis. In such a situation, investing in new, additional solutions may mean the waste of resources. It may be better to invest in strengthening existing 
resources i.e. supporting competent members of an organization in acquiring knowledge, giving them tools and helping them to break the barriers which impede knowledge flow within an organization. The efforts should focus on supporting the flow of information regarding relationships of the various groups of stakeholders, and increasing the priority of this knowledge, rather than be wasted on investment in new, centralized activities or building alternative channels of acquiring knowledge by organizing "stakeholder panels".

As far as "stakeholder panels", in the form described above, are not considered as the most effective solution, it does not mean that organizing such meetings, or even establishing this type of bodies is useless. However, the following issues should be highlighted when organizing "stakeholder panels":

- selecting carefully the members of the group of experts and authorities, representing the key stakeholder groups;

- making cooperation regular and cyclical.

The structure of a "stakeholder panel" should be close to a typical advisory body consisting of permanent experts rather than the members participating on a random basis. The panel should meet in a cyclical pattern e.g. once or twice a year. The Supervisory Board could consult its decisions with such a body. The panel members would have an access to knowledge about dialogue with a wide representation of stakeholders and a good understanding of the company situation. It would be an equivalent of Program Councils in NGOs, which are separated from Foundation Councils (equivalents to the supervisory boards of public limited-liability companies), and support the Foundation's authorities in the development of optimal solutions. Such a "panel of stakeholders" seems to fit the structure of managerial and supervisory bodies of business companies.

It is worth pointing out that existing regulations enable supervisory councils to appoint experts as independent advisors. Therefore, it is possible to establish a position or an advisory body responsible for the issues of corporate social responsibility which could play the role mentioned above. In order to identify whether such a solution is applied in business practice, the structures of top 25 corporations ranked in the 2012 Fortune 500 list $^{4}$ are analyzed in Table 2. The committees responsible for CSR are printed in bold.

4 http://fortune.com/fortune500/2012/ (06 Mar. 2014). 
Table 2. CSR committees in 2012 top 25 world corporations

\begin{tabular}{|c|c|c|c|}
\hline No. & $\begin{array}{l}\text { Company/ } \\
\text { capital group }\end{array}$ & $\begin{array}{l}\text { Body } \\
\text { (committee) } \\
\text { responsible for } \\
\text { CSR issues }\end{array}$ & $\begin{array}{l}\text { Committees under } \\
\text { the Board of Directors }\end{array}$ \\
\hline 1. & Exxon Mobil & yes & $\begin{array}{l}\text { Audit Committee } \\
\text { Compensation Committee } \\
\text { Board Affairs Committee } \\
\text { Finance Committee } \\
\text { Public Issues and Contributions Committee } \\
\text { Executive Committee }\end{array}$ \\
\hline 2. & $\begin{array}{l}\text { Wal-Mart } \\
\text { Stores }\end{array}$ & yes & $\begin{array}{l}\text { Audit Committee } \\
\text { Compensation, Nominating and Governance } \\
\text { Committee } \\
\text { Executive Committee } \\
\text { Global Compensation Committee } \\
\text { Strategic Planning and Finance Committee } \\
\text { Technology and eCommerce Committee }\end{array}$ \\
\hline 3. & Chevron & yes & $\begin{array}{l}\text { Audit Committee } \\
\text { Board Nominating \& Governance Committee } \\
\text { Management Compensation Committee } \\
\text { Public Policy Committee }\end{array}$ \\
\hline 4. & ConocoPhillips & yes & $\begin{array}{l}\text { Audit \& Finance Committee } \\
\text { Human Resources \& Compensation Committee } \\
\text { Public Policy Committee } \\
\text { Committee on Directors Affairs } \\
\text { Executive Committee }\end{array}$ \\
\hline 5. & $\begin{array}{l}\text { General } \\
\text { Motors }\end{array}$ & yes & $\begin{array}{l}\text { Audit Committee } \\
\text { Directors \& Corp. Governance Committee } \\
\text { Executive Compensation Committee } \\
\text { Finance \& Risk Committee } \\
\text { Public Policy Committee } \\
\text { Executive Committee }\end{array}$ \\
\hline 6. & $\begin{array}{l}\text { General } \\
\text { Electric }\end{array}$ & yes & $\begin{array}{l}\text { Audit Committee } \\
\text { Management Development and Compensation } \\
\text { Committee } \\
\text { Nominating and Corporate Governance Committee } \\
\text { The Public Responsibilities Committee } \\
\text { Risk Committee }\end{array}$ \\
\hline 7. & $\begin{array}{l}\text { Berkshire } \\
\text { Hathaway }\end{array}$ & no & $\begin{array}{l}\text { Audit Committee } \\
\text { Governance, Compensation and Nominating } \\
\text { Committee } \\
\text { Executive Committee }\end{array}$ \\
\hline
\end{tabular}




\begin{tabular}{|c|c|c|c|}
\hline No. & $\begin{array}{l}\text { Company/ } \\
\text { capital group }\end{array}$ & $\begin{array}{c}\text { Body } \\
\text { (committee) } \\
\text { responsible for } \\
\text { CSR issues }\end{array}$ & $\begin{array}{l}\text { Committees under } \\
\text { the Board of Directors }\end{array}$ \\
\hline 8. & Fannie Mae & no & $\begin{array}{l}\text { Audit Committee } \\
\text { Compensation Committee } \\
\text { Executive, Nominating \& Corporate Governance } \\
\text { (N \& CG) Committee } \\
\text { Risk Policy \& Capital (RP \& C) Committee } \\
\text { Strategic Initiatives Committee. }\end{array}$ \\
\hline 9. & Ford Motor & yes & $\begin{array}{l}\text { Audit Committee } \\
\text { Compensation Committee } \\
\text { Finance Committee } \\
\text { Nominating and Governance Committee } \\
\text { Sustainability Committee }\end{array}$ \\
\hline 10. & $\begin{array}{l}\text { Hewlett-Pack- } \\
\text { ard }\end{array}$ & yes & $\begin{array}{l}\text { Audit Committee } \\
\text { Finance and Investment Committee } \\
\text { HR and Compensation Committee } \\
\text { Nominating and Governance Committee } \\
\text { Technology Committee }\end{array}$ \\
\hline 11. & AT \& T & yes & $\begin{array}{l}\text { Audit Committee } \\
\text { Corporate Development and Finance Committee } \\
\text { Corporate Governance and Nominating } \\
\text { Committee } \\
\text { Executive Committee } \\
\text { Human Resources Committee } \\
\text { Public Policy and Corporate Reputation } \\
\text { Committee }\end{array}$ \\
\hline 12. & Valero Energy & yes & $\begin{array}{l}\text { Executive Committee } \\
\text { Nominating Governance and Public Policy } \\
\text { Committee } \\
\text { Audit Committee } \\
\text { Compensation Committee }\end{array}$ \\
\hline 13. & $\begin{array}{l}\text { Bank of } \\
\text { America } \\
\text { Corporation }\end{array}$ & no & $\begin{array}{l}\text { Audit Committee } \\
\text { Compensation and Benefits Committee } \\
\text { Corporate Governance Committee Credit } \\
\text { Committee } \\
\text { Enterprise Risk Committee } \\
\text { Executive Committee }\end{array}$ \\
\hline 14. & McKesson & no & $\begin{array}{l}\text { Audit Committee } \\
\text { Compensation Committee } \\
\text { Committee on Directors and Corporate } \\
\text { Governance } \\
\text { Finance Committee }\end{array}$ \\
\hline
\end{tabular}




\begin{tabular}{|c|c|c|c|}
\hline No. & $\begin{array}{l}\text { Company/ } \\
\text { capital group }\end{array}$ & $\begin{array}{l}\text { Body } \\
\text { (committee) } \\
\text { responsible for } \\
\text { CSR issues }\end{array}$ & $\begin{array}{l}\text { Committees under } \\
\text { the Board of Directors }\end{array}$ \\
\hline 15. & $\begin{array}{l}\text { Verizon Com- } \\
\text { munications }\end{array}$ & yes & $\begin{array}{l}\text { Audit Committee } \\
\text { Corporate Governance and Policy Committee } \\
\text { Human Resources Committee }\end{array}$ \\
\hline 16. & $\begin{array}{l}\text { J.P. Morgan } \\
\text { Chase \& Co. }\end{array}$ & yes & $\begin{array}{l}\text { Audit Committee } \\
\text { Compensation \& Management Development } \\
\text { Committee } \\
\text { Corporate Governance \& Nominating } \\
\text { Committee } \\
\text { Public Responsibility Committee } \\
\text { Risk Policy Committee }\end{array}$ \\
\hline 17. & Apple & no & $\begin{array}{l}\text { Audit Committee } \\
\text { Compensation Committee } \\
\text { Nominating and Corporate Governance } \\
\text { Committee }\end{array}$ \\
\hline 18. & CVS Caremark & no & $\begin{array}{l}\text { Audit Committee } \\
\text { Management Planning and Development } \\
\text { Committee } \\
\text { Nominating and Corporate Governance } \\
\text { Committee }\end{array}$ \\
\hline 19. & $\begin{array}{l}\text { International } \\
\text { Business } \\
\text { Machines } \\
\text { (IBM) }\end{array}$ & yes & $\begin{array}{l}\text { Audit Committee } \\
\text { Directors and Corporate Governance } \\
\text { Committee } \\
\text { Executive Compensation and Management } \\
\text { Resources Committee } \\
\text { Executive Committee }\end{array}$ \\
\hline 20. & Citigroup & yes & $\begin{array}{l}\text { Audit Committee } \\
\text { Governance and Public Affairs Committee } \\
\text { Personnel and Compensation Committee } \\
\text { Risk Management and Finance Committee }\end{array}$ \\
\hline 21. & $\begin{array}{l}\text { Cardinal } \\
\text { Health }\end{array}$ & no & $\begin{array}{l}\text { Audit Committee } \\
\text { Nominating and Governance Committee } \\
\text { Compensation Committee } \\
\text { Executive Committee }\end{array}$ \\
\hline 22. & $\begin{array}{l}\text { UnitedHealth } \\
\text { Group }\end{array}$ & yes & $\begin{array}{l}\text { Audit Committee } \\
\text { Compensation and Human Resources Committee } \\
\text { Public Policy Strategies and Responsibility } \\
\text { Committee } \\
\text { Nominating and Corporate Governance } \\
\text { Committee }\end{array}$ \\
\hline
\end{tabular}




\begin{tabular}{llcl}
\hline No. & $\begin{array}{c}\text { Company/ } \\
\text { capital group }\end{array}$ & $\begin{array}{c}\text { Body } \\
\text { (committee) } \\
\text { responsible for } \\
\text { CSR issues }\end{array}$ & \multicolumn{1}{c}{$\begin{array}{c}\text { Committees under } \\
\text { the Board of Directors }\end{array}$} \\
\hline 23. & Kroger & yes & $\begin{array}{l}\text { Audit Committee } \\
\text { Compensation Committee } \\
\text { Corporate Governance Committee } \\
\end{array}$ \\
& & The Financial Policy Committee \\
& & Public Responsibility Committee \\
\hline 24. & Costco & Audit Committee \\
& Wholesale & & $\begin{array}{l}\text { Compensation Committee } \\
\text { Nominating and Governance Committee }\end{array}$ \\
\hline 25. & Freddie Mac & no & $\begin{array}{l}\text { Audit Committee } \\
\text { Business and Risk Committee } \\
\end{array}$ \\
& & Compensation Committee \\
& & Coordinating Committee \\
& & Nominating and Governance Committee \\
\hline
\end{tabular}

Source: Own study based on social company websites.

The list is dominated by American companies whose management structure is one-level structure, i.e. there is not a separate Board of Directors and a Supervisory Board, but within the framework of a socalled Board of Directors, executive and non-executive directors exist together. Executive directors can be equated with a Board, and non-executive directors with a Supervisory Board. Similarly to the solutions applied in European companies, including Poland, in these companies there are committees e.g. Audit Committees or Remuneration Committees. It is worth mentioning that the committees dealing with corporate social responsibility are more and more often included in the governance structure e.g. Public Responsibility Committees, Public Policy Committees or Sustainability Committees. In some cases, CSR issues were included in the responsibility of Remuneration Committees or Corporate Governance Committees.

The findings presented above still need further confirmation. Nevertheless, they seem to indicate the trend of transition from the Stakeholders Theory to the Enlightened Shareholders Theory. The traditional function of Supervisory Boards, which is corporate governance on behalf of the shareholders exclusively, will probably evaluate to corporate governance taking into account the interests of other shareholders. It seems to be the logical consequence of the company responsibility to all the 
groups of stakeholders. It means that there is a space not only for a CSR Committee supporting a Management Board, but also for a Supervisory Board Committee on Corporate Social Responsibility, even if its role is reduced to an advisory body. Such bodies should be responsible for analyzing information acquired from stakeholders, and taking them into decision-making processes. This is a possible direction which should be followed by the companies interested in engaging their stakeholders.

\section{Conclusions}

The paper has outlined the issue of the company dialogue with its stakeholders which is considered to be one of the contemporary challenges for management and business leaders. The dilemmas associated with the consequences of the transition from the management based on the Shareholders Theory towards the Stakeholders Theory and the Enlightened Shareholders Theory have been discussed. Nevertheless, the problems of the company dialogue with its environment need further research. Although Freeman's seminal work was published 30 years ago, managers are still very reluctant to put the theory into practice. They seem to be oriented to short-term superficial activities aimed at building brand image rather than long-term solutions. In consequence, the effectiveness of managing knowledge of stakeholders' expectations requires improvements. The avoidance of the problems increases the level of uncertainty, while effective solutions based on corporate governance structures seem to be relatively easy to be implemented. Nowadays, it is difficult to decide whether establishing corporate social responsibility bodies at the level of Supervisory Board, as proposed in the paper, is an optimal solution. Nevertheless, it is certainly a solution which applies a reliable and systematic approach to extent the management focus beyond financial results and to include the economic, social and environmental aspects of a company impact on its environment. Without the real engagement of managers, corporate social responsibility will remain on the peripheries of a company, rather than being its core element. 


\section{Bibliography}

Dymowski, J. (2012), Problemy wpływu społecznej odpowiedzialności biznesu na wyniki finansowe przedsiębiorstwa, SGH, Warszawa, (Ph.D. thesis).

Dymowski, J. (2014), “Dialog jako źródło wartości biznesowej”, in: Dialog z interesariuszami: Jak rozmawiać, czyli jak usłyszeć i jak zostać wysłuchanym, Konfederacja Lewiatan, Warszawa, pp. 30-49.

Evan, W.M., Freeman, R. (1988), “A Stakeholder Theory of the Modern Corporation: Kantian Capitalism”, in: Beauchamp, T., Bowie, N. (Eds.), Ethical Theory and Business, Prentice Hall, New York, pp. 75-93.

Freeman, R. (1984), Strategic Management: A Stakeholder Approach, Pitman, Boston.

Freeman, R., Liedtka, M. (1991), “Corporate Social Responsibility: A Critical Approach”, Business Horizons, Vol. 34, Issue 4, pp. 92-99.

Freeman, R., Reed, D. (1983), "Stockholders and Stakeholders: A New Perspective on Corporate Governance”, in: Huizinga C.J. (Ed.), Corporate Governance: A Definitive Exploration of the Issues, University Press, Los Angeles.

Freeman, R., Velmuri R., (2006), “A New Approach to CSR: Company Stakeholder Responsibility”, in: Kakabadse, A., Morsing, M. (Ed.), Corporate Social Responsibility (CSR): Reconciling Aspirations with Application, Palgrave Macmillan, Basingstoke, pp. 9-23.

GRI (2013), G4 Sustainability Reporting Guidelines: Reporting Principles and Standard Disclosures, Global Reporting Initiative, Amsterdam.

Jensen, M. (1984), “Agency Costs of Free Cash Flow, Corporate Finance, and Ownership Structure”, American Economic Review, Vol. 76, No. 2, pp. 323-329.

Jones, T. (1980), “Corporate Social Responsibility Revisited, Redefined”, California Management Review, Vol. 22, Issue 3, pp. 59-67.

Mele, D. (2009), “Corporate Social Responsibility Theories”, in: Crane, A., Matten, D., McWilliams, A., Moon, J., Siegel, D.S. (Eds.), The Oxford Handbook of Corporate Social Responsibility, Oxford University Press, Oxford, pp. 47-83.

Marcoux, A.M. (2000), “Balancing Act”, in: Dasjardins J., MacCall J. (Eds.), Contemporary Issues in Business Ethics, Wadsworth, Belmont, pp. 1-24.

Obłój, K. (2010), Pasja i dyscyplina strategii: Jak z marzeń i dyscypliny zbudować sukces firmy, Poltext, Warszawa.

PN-ISO 26000 (2011), Wytyczne dotyczqce społecznej odpowiedzialności, PKN, Warszawa.

Sternberg, E. (2000), Just Business: Business Ethics in Action, Oxford University Press, Oxford. 
